\title{
Management of subdural empyema: a series of 24 cases
}

\author{
ELIZABETH S MILLER, P S DIAS, DAVID UTTLEY \\ Atkinson Morley's Hospital, London, UK
}

SUMMARY Twenty four cases of subdural empyema are reviewed. The overall mortality was $17 \%$, 18 patients were managed by burr hole and five by craniotomy or craniectomy. Antibiotic therapy was commenced once pus had been evacuated. Infection of the paranasal and mastoid sinuses was the commonest aetiological factor. Aspiration of pus through burr holes is the recommended surgical procedure with low mortality and morbidity, when combined with early diagnosis and aggressive chemotherapy.

Subdural empyema is a relatively rare manifestation of intracranial sepsis, rapid in evolution and potentially lethal in outcome. Approximately one fifth of intracranial suppuration will take this form and between 15 and $40 \%$ of patients are likely to die. ${ }^{12}$ The outcome depends on many factors, in particular early diagnosis, clinical state, causative organism, source of empyema and age of the patient. ${ }^{3}$ Survival has gradually improved over recent decades during which time there has been an increasing tendency to employ craniotomy as the primary surgical procedure. $^{4}$

This report aims to show that aspiration of pus through burr holes is a simple and effective form of management with low mortality and morbidity when therapy swiftly follows early diagnosis.

Twenty three cases of subdural empyema referred to the Atkinson Morley's Hospital between 1971 and 1984 are reviewed. The overall mortality was $17 \%$. The diagnosis was first made at necropsy in one further case not included in the subsequent analysis.

\section{Clinical features}

Eighteen were male and five were female. Mean age was 31 years. The duration of symptoms prior to diagnosis ranged from 24 hours to 8 weeks. The majority had symptoms for less than 2 weeks and 20 had a history of less than 3 weeks. Most presented with severe headache (15), neurological deficit (12), deteriorating conscious level (11) and epilepsy

Address for reprint requests: Mr D Uttley, Atkinson Morley's Hospital, Copse Hill, London SW20 ONE, UK.

Received 10 June 1986 and in final revised form 31 March 1987. Accepted 2 April 1987
(8). On arrival at this hospital six were alert, 16 were drowsy and one was deeply comatose. Mortality in these patients was $17 \%, 13 \%$ and $100 \%$ respectively. Twenty one had a focal neurological deficit: 15 a hemiparesis, three hemiparesis and dysphasia, two a hemianopia and one cerebellar dysfunction.

Age alone significantly influenced survival: of four patients over the age of 60 , three died, of 19 patients under that age, only one died ( $p=0.01$ chi-squared with Yates correction).

\section{Aetiology (table 1)}

Infection spread from the paranasal sinuses in eight cases and mastoid sinuses in seven. Eleven had received treatment for these infections, but went on to develop subdural empyema. Three had undergone previous neurosurgical operation: burr holes for subdural haematoma, craniotomy for repair of anterior cranial fossa cerebrospinal fluid leak, and craniotomy for extradural haematoma. Three had sustained recent head injury, one was due to metastatic spread of infection, and in one no cause was found.

Bacteria were cultured in all but one case. Single species were cultured in 13 cases and multiple species in nine. The commonest organism was the non-haemolytic streptococcus (in seven), anaerobic organisms were cultured in five cases (table 1).

\section{Diagnosis}

Investigations included computed tomography, radioisotope scanning and air ventriculography. Thirteen patients had one or more CT scans, nine were diagnostic, three abnormal and one was "normal" (this occurred in the first year of computed tomography and contrast was not used; the diagnosis was made following angiography and isotope scanning). Eleven radioisotope scans were performed: nine were diagnostic, one abnormal and one normal. Six angiograms were performed and all showed extracerebral collections. Two air ventriculograms were performed, one 
Table 1 Subdural abscess: bacteriological details

\begin{tabular}{|c|c|c|}
\hline $\begin{array}{l}\text { Source of } \\
\text { infection }\end{array}$ & $\begin{array}{l}\text { No } \\
\text { cases }\end{array}$ & Bacteria cultured (no of cases) \\
\hline $\begin{array}{c}\text { Paranasal } \\
\text { sinuses }\end{array}$ & 8 & $\begin{array}{l}\text { Non-haemolytic strep. (3)*, } \\
\text { microaerophilic strep. (3), Staph } \\
\text { aureus (1), B fragilis (1), Staph } \\
\text { albus (1), Strep. viridans (1). }\end{array}$ \\
\hline $\begin{array}{l}\text { Mastoid } \\
\text { sinuses }\end{array}$ & 7 & $\begin{array}{l}\text { Anaerobes }(3), \text { proteus }(2), \\
\text { non-haemolytic strep. }(1),^{*} \text { gram } \\
\text { positive cocci }(1), \beta \text {-haem. strep. } \\
(1)^{*} \text { no growth }(1)^{*} \text {. }\end{array}$ \\
\hline $\begin{array}{l}\text { Previous } \\
\text { head injury }\end{array}$ & 3 & $\begin{array}{l}\text { E. coli (1), anaerobes (1), non-haem } \\
\text { strep. (1). }\end{array}$ \\
\hline $\begin{array}{l}\text { Previous } \\
\text { surgery }\end{array}$ & 2 & $\begin{array}{l}\text { Staph albus (2), Strep. } \\
\text { pneumoniae (1). }\end{array}$ \\
\hline $\begin{array}{l}\text { Previous } \\
\text { abscess }\end{array}$ & 1 & Staph albus, anaerobes. \\
\hline $\begin{array}{l}\text { Metastic } \\
\text { spread }\end{array}$ & 1 & Non-haem strep., Strep. milleria. \\
\hline Unknown & 1 & Strep. pneum, microaerophilic strep. \\
\hline
\end{tabular}

* = deaths

showed a space occupying lesion in the posterior fossa, the other was unhelpful.

Site of the abscess

Sixteen had subdural empyema without other pathology, two $(12 \%)$ of whom died. Four had an additional extradural collection and one patient had an extradural and intracerebral abscess, there were no deaths in this group; two had an associated intracerebral abscess, both died. There was one subtentorial empyema.

\section{Treatment}

Surgery was performed in conjunction with topical and systemic antibiotic therapy, 18 were treated with one or more burr holes and 16 had subdural catheters positioned to allow drainage and administration of antibiotics into the subdural space. Craniotomy was subsequently required in one case for a persistent collection of fluid. There were three deaths $(17 \%)$. Two underwent primary craniotomy, one re-opening of craniotomy and one craniectomy. There was one death. One case underwent posterior fossa craniectomy.

Antibiotic therapy was commenced as soon as the pus had been evacuated. The most commonly used antibiotics were chloramphenicol and penicillin, with metronidazole where appropriate. Fifteen patients received $16 \mathrm{mg}$ dexamethasone daily in the first week.

\section{Outcome (table 2)}

Sixteen patients made a good recovery and were without deficit on discharge from hospital or at routine follow-up. Two patients were discharged with mild hemiparesis, one of whom was lost to follow-up. A further patient with hemiplegia died 3 months after discharge at the referring hospital. Seven surviving patients developed epilepsy.

\section{Mortality}

There were four deaths. The causes of death were status epilepticus, developing 24 hours after surgery, sagittal sinus thrombosis and venous infarction, raised intracranial pressure associated with an undiagnosed intracerebral abscess; the fourth patient died 3 months following discharge at the referring hospital; there was no necropsy.

A fifth patient came to necropsy before the diagnosis had been made and is not included in the above analysis. He was initially treated for tuberculous meningitis on the basis of lumbar puncture and CT findings. Post mortem examination revealed bilateral subdural empyemas without a septic focus; streptococcus milleria and $\beta$-haemolytic streptococci were cultured from the pus.

\section{Discussion}

Infection of the paranasal or mastoid sinuses is the commonest associated cause of subdural empyema. In the present study, $60 \%$ of patients suffered underlying sinus disease. The highest mortality (43\%) occurred in conjunction with mastoid disease. A more benign form of empyema rarely follow surgery for subdural haematoma. ${ }^{5}$ Spontaneous empyema is rare, but three cases in this series followed relatively minor head trauma some weeks before.

The illness is characterised by severe headache, rapidly advancing neurological deficit, and epilepsy, combined with evidence of underlying infection.

The majority of patients in this series were drowsy at the time of referral, but physical signs could not be correlated with mortality because of the small number of cases.

During the early part of this series cerebral angiography and isotope scan were performed in conjunction with computed tomography. With increased experience and the introduction of later generation scanners, computed tomography provided a specific diagnosis in all cases. As with cerebral abscesses, the introduction of computed tomography should have a beneficial effect on outcome, ${ }^{67}$ not least as the diagnosis was often first made post mortem in many early series. ${ }^{89}$

Antibiotics alone have allowed this condition to be

Table 2 Presentation and outcome for each treatment modality

\begin{tabular}{|c|c|c|c|c|c|c|}
\hline & Alert & Drowsy & Comatose & $\begin{array}{l}\text { Good } \\
\text { recovery }\end{array}$ & Deficits & Death \\
\hline $\begin{array}{l}\text { Burr hole } \\
\text { Burr hole aspiration, subsequent craniotomy } \\
\text { Craniotomy, craniectomy reopening } \\
\text { Posterior fossa } \\
\text { Total }\end{array}$ & $\begin{array}{l}4 \\
1 \\
1 \\
6\end{array}$ & $\begin{array}{r}12 \\
1 \\
3 \\
16\end{array}$ & 1 & $\begin{array}{r}12 \\
1 \\
3 \\
1 \\
17\end{array}$ & 2 & $\begin{array}{l}3 \\
1 \\
4\end{array}$ \\
\hline
\end{tabular}


amenable to neurosurgical management. Subdural empyema was almost always fatal before penicillin was available for topical and systemic use. Schiller vividly showed its beneficient impact on survival in 1948. ${ }^{10}$ Chloramphenicol and penicillin remain the primary treatment until specific antibiotic sensitivities are known and treatment is continued for several weeks. Streptococcal infection is still found in a high proportion of fatal cases (table 2). ${ }^{211}$ Metronidazole readily crosses into intracranial pus and is effective against the anaerobic organisms commonly found in association with mastoid air cell disease. ${ }^{12-14}$

The exhibition of antibiotics prior to culture of the infected material leads to a poor yield of organisms. ${ }^{15}$ While this showed that the drugs reach their targets rapidly, the laboratory is thwarted in its attempt to indicate the apposite chemotherapy.

There is a recent trend towards wide decompressive craniotomy, as an initial manoeuvre in all cases of subdural empyema. This has been advocated by several authors emphasising surgical technique $^{341617}$ rather than aspects which we believe to be of more crucial importance, namely early diagnosis and speedy surgical intervention. Deteriorating patients are likely to receive the lesser procedure of burr hole aspiration which will distort retrospective comparison.

A review of previous reports of subdural empyema (table 3) illustrates the poor documentation of most patients suffering this condition. The mortality associated with burr hole aspiration is higher than that associated with craniotomy. It is also apparent that most authors have employed both procedures, and information is not available as to why a particular approach was chosen, or the clinical condition of the patient prior to surgery. The majority of series are small and therefore highly selective.

In the early stages, the pus is liquid, thickening only as the disease progresses; thus in the early stages burr hole aspiration is sufficient treatment. Advocates of wide decompressive craniotomy claim that a better decompression can be achieved with removal of larger quantities of infected material. However, the volume of pus may be small in comparison to the extent of vasogenic oedema, which may be the major contributor to raised intracranial pressure, and this can usually be controlled with osmotic diuretics.

The traditional method of management of this condition is the evacuation of pus through multiple burr holes and the instillation of antibiotics into the cavity by subdural catheters. CT permits the accurate placement of burr holes. ${ }^{18}$ The majority of patients were managed in this way using one or more appropriately sited burr holes. It proves to be a successful method of treatment with low perioperative mortality $(12 \%)$ where subdural empyema is the only pathology. This compares well with Bannister's predicted mortality of $9 \%$ in uncomplicated cases selected for primary craniotomy. ${ }^{4}$

One patient died following burr hole aspiration having an undiagnosed intracerebral abscess. This case occurred before the introduction of computed

Table 3 Outcome of both major treatment modalities: analysis of collected series

\begin{tabular}{|c|c|c|c|c|c|c|c|}
\hline Burr hole & No & \multicolumn{3}{|c|}{ Alert/Drowsy/Comatose } & Good recovery & Deficits & Death \\
\hline $\begin{array}{l}\text { Bannister }^{4} \\
\text { Torres }^{9} \\
\text { Keith }^{20} \\
\text { Stephanov } \\
\text { Coonrod }^{21} \\
\text { Wood }^{22} \\
\text { Garfield }^{1} \\
\text { Borzone }^{15} \\
\text { Le Beau }^{11} \\
\text { Kaufman }^{2} \\
\text { Smith }^{23}\end{array}$ & $\begin{array}{r}43 \\
3 \\
4 \\
7 \\
1 \\
11 \\
20 \\
2 \\
11 \\
3 \\
10\end{array}$ & $\begin{array}{r}\text { Not } \\
2 \\
\text { Not } \\
5 \\
\\
\text { Not } \\
1 \\
\text { Not } \\
2 \\
\text { Not }\end{array}$ & $\begin{array}{l}\text { ilab } \\
\text { ilab } \\
1 \\
5 \\
\text { ilab } \\
1 \\
\text { ilab } \\
1 \\
\text { ilab }\end{array}$ & 1 & $\begin{array}{l}25 \\
4 \\
4 \\
1 \\
7 \\
8 \\
2 \\
\text { Not available } \\
2 \\
10\end{array}$ & $\begin{array}{l}1 \\
1\end{array}$ & $\begin{array}{r}2 \\
4 \\
11\end{array}$ \\
\hline Total & 110 & 10 & 8 & 9 & 63 & 4 & 45 \\
\hline $\begin{array}{l}\text { Craniotomy } \\
\text { Borzone }^{15} \\
\text { Le Beau }^{11} \\
\text { Kaufman }^{2} \\
\text { Bannister }^{4} \\
\text { Post }^{5} \\
\text { Smith }^{23} \\
\text { Torres }^{9} \\
\text { Keith }^{20} \\
\text { Coonrod }^{21} \\
\text { Luken }^{17} \\
\text { Van Alpen }^{3}\end{array}$ & $\begin{array}{r}12 \\
26 \\
14 \\
24 \\
4 \\
4 \\
9 \\
3 \\
6 \\
6 \\
16\end{array}$ & $\begin{array}{r}3 \\
\text { Not } \\
8 \\
\text { Not } \\
\text { Not } \\
\text { Not } \\
7 \\
\text { Not } \\
1 \\
4 \\
\text { Not }\end{array}$ & $\begin{array}{l}7 \\
\text { ilab } \\
3 \\
\text { ilab } \\
\text { ilab } \\
\text { ilab } \\
2 \\
\text { ilab } \\
4 \\
1 \\
\text { iilab }\end{array}$ & $\begin{array}{l}2 \\
3\end{array}$ & $\begin{array}{l}8 \\
\text { Not available } \\
11 \\
11 \\
4 \\
4 \\
7 \\
3 \\
4 \\
3 \\
5\end{array}$ & $\begin{array}{r}2 \\
1 \\
11\end{array}$ & $\begin{array}{l}2 \\
6 \\
6 \\
2\end{array}$ \\
\hline Total & 124 & 23 & 17 & 7 & 60 & 26 & 16 \\
\hline
\end{tabular}


tomography. It is conceivable that had a craniotomy been performed this additional pathology would have been demonstrated. The two remaining perioperative deaths resulted from sagittal sinus thrombosis and status epilepticus.

In Bannister's series those who survived craniotomy had a higher incidence of neurological deficit $(29 \%)$ at late follow-up than those managed with burr holes. This did not reach statistical significance. ${ }^{4}$ In the present series only one patient had a confirmed neurological deficit at one year. These results raise the possibility that pre-existing deficits are exacerbated by major neurosurgical procedures which have not yet been shown to improve survival.

Epilepsy remains a significant cause of late morbidity. In this series $31 \%$ of patients discharged from hospital continued to suffer fits. This compares with $26 \%$ reported by Hitchcock and Andreadis, ${ }^{8} 37 \%$ by Borzone et al $^{15}$ and $33 \%$ by Cowie and Williams ${ }^{19}$ despite the prescription of anticonvulsant therapy.

\section{Conclusions}

There need be no overt signs of raised intracranial pressure or infection associated with subdural empyema, although paranasal or mastoid sinus sepsis is common and should alert the clinician to the possibility of this development.

Improved survival during this decade reflects more accurate diagnosis achieved by the use of computed tomography combined with earlier referral rather than by profound changes in surgical technique. Accurately located burr holes are adequate for satisfactory treatment in the majority of cases.

We thank Miss S Rostron for her never failing help and patience in the preparation of this manuscript.

\section{References}

1 Garfield J. Management of supratentorial intracranial abscess: a review of 200 cases. $\mathrm{Br} \mathrm{Med} J$ 1969;2:7-11.
2 Kaufman DM, Litman N, Miller MH. Sinusitis induced empyema. Neurology 1983;33:123-32.

3 Van Alpen HAM, Dreisen JJR. Brain abscess and subdural empyema. Factors influencing mortality and results of various surgical techniques. $J$ Neurol Neurosurg Psychiatry 1976;39:481.

4 Bannister G, Williams B, Smith S. Treatment of subdural empyema. J Neurosurg 1981;55:82-8.

5 Post EM, Modesti LM. "Subacute" post-operative subdural empyema. J Neurosurg 1980;55:477.

6 Jefferson AA, Keogh AJ. Intracranial abscess: a review of treated patients over 21 years. $Q J$ Med 1977;183:389-400.

7 Mousa AH, Dawson BH. Computed tomography and the mortality rate in brain abscess. Surg Neurol 1978;10:301-4.

8 Hitchcock E, Andreadis A. Subdural empyema: a review of 29 cases. J Neurol Neurosurg Psychiatry 1964;27: 422.

9 Torres H, Yarzagary L, West C. Subdural empyema angiographic considerations. Neurochirurgia 1970;13 201.

10 Schiller F, Cairns H, Russel D. The treatment of purulent pachymeningitis and subdural suppuration with specific reference to Penicillin. J Neurol Neurosurg Psychiatry 1948;11:143-82.

11 Le Beau J, Creissand P, Harispe L, et al. Surgical treatment of subdural empyema. $J$ Neurosurg 1973;38: 198-203.

12 De Louvois J, Gortvai P, Hurley R. Bacteriology of abscesses of the central nervous system: a multicentre prospective trial. $\mathrm{Br}$ Med J 1877;2:981-4.

13 De Louvois J, Gortvai P, Hurley R. Antibiotic treatment of abscesses of the central nervous system. Br Med $J$ 1977;2:985-7.

14 Ingham HR, Selham JB, Roxby CM. Bacteriological study of otogenic cerebral abscesses: chemotherapeutic role of metronidazole. Br Med J 1977;2:991-3.

15 Borzone M, Capuzzo T, Rivano C, et al. Subdural empyema: fourteen cases surgically treated. Surg Neurol 1980;13:449-52.

16 Alderson D, Strong AD, Ingham HR, et al. Fifteen years review of the mortality of brain abscess. Neurosurgery 1981;81:1-6.

17 Luken MG. Recent diagnostic experiences with subdural empyema. J Neurosurg 1980;52:764-71.

18 Stephanov S. Combined convexity and parafalcine subdural empyema. Surg Neurol 1979;2:147-51.

19 Cowie R, Williams B. Late seizures and morbidity after subdural empyema. J Neurosurg 1983;58:569-73.

20 Keith N. Subdural empyema. $J$ Neurosurg 1949;6: 127-39.

21 Coonrod JD, Dans PE. Subdural empyema. Am J Med 1975;58:99-104.

22 Wood PH. Diffuse subdural suppuration. $J$ Laryngol 1952;66:496-510.

23 Smith HP, Hendrick EB. Subdural empyema and epidural abscess in children. $J$ Neurosurg 1983;58:392-7. 